\title{
Peculiar Features of Non-Verbal Means of Communication among Children with Normal Eyesight and Visually Challenged Children of High Preschool Age
}

\section{Liubov Okonechnikova}

Ural Federal University named after the first President of Russia B. N. Yeltsin (Russia, Yekaterinbrg)

\section{Abstract}

It is known, that visually challenged children acquire non-verbal means of communication less spontaneously. It is more common for them to use single and definite gestures and frequently provide them with some verbal explanations, incorrect perception of gestures and miming, poorness or lack of movements. Based on A.R.Luria's idea of the role of the environment in a child's personality formation, and compensatory

Corresponding Author: Liubov Okonechnikova dokonechnikov@mail.ru

Received: 25 July 2018

Accepted: 9 August 2018

Published: 1 November 2018

Publishing services provided by Knowledge

(c) Liubov Okonechnikova. This article is distributed under the terms of the

Attribution License, which permits unrestricted use and redistribution provided that the original author and source are credited.

Selection and Peer-review under the responsibility of the Fifth International Luria Memorial Congress Conference Committee. developing mechanisms and also on some ideas of modern researchers that nonverbal means of communication are connected with social conditions and usually are formed during the life with the exception of means of affective expressiveness (G.V. Grigirieva, L.I.Plaksina, L.I.Solntseva), we have made a comparative study of using nonverbal means of communication among children with normal eyesight and visually challenged children.

As research approaches we modify and use such techniques as "The ABC of Mood" by N.L.Belopolskaya, "Silence game" by G.V.Grigorieva, "Understanding of gestures" by N.V.Pilipko and "Understanding of Miming" by Sabin and Hardick modified by G.V. Grigorieva. We have examined 36 children of high preschool age, 18 of them were with normal eyesight and 18 were visually challenged, and all of them were taught how to acquire non-verbal means of communication.

We have found out that children from both groups could not differentiate similar facial expressions and gestures, miming usually was described through actions, not through feelings or emotions. The results showed us the absence of defining facial expressions, gestures and miming on the levelb of cognition and behavior between these two groups of children. On the level of emotions, we had had the following differences: the children with normal eyesight rarely explain gestures through actions then visually challenged children and also they rarely connect the emotional state with the situation, but more often they distinguish miming through explaining some physical characteristics, that may depend on their visual problem.

So we can conclude that if we organize the process of education in the right way (the role of the environment) visually challenged pre-school aged children can have the partial ability to compensate their acquirement of non-verbal means of communication. pre-school aged children, visually challenged. 


\section{Introduction}

Among scientists who study the psychology of the blind, we can distinguish the following opinions about how the loss of sight influences on mental activity of preschool ages children.

Based on the idea that education of visually challenged children happens in the same way as the education of children with normal eyesight, some scientists notice that such children have more extended and developed attention span [1], enhanced capability to control and operate it [2], there is no differences in memory improvement $[1,3]$, their mentality and speech may be of a very high level [4]. Mind, memory, emotions, feelings, imagination, mentality and other mental processes are subdued to one main tendency - to compensate (to balance) the loss of sight.

However, visually challenged children have some problems with visual-motor and emotional-volitional spheres that can be shown through the lack of confidence, clumsiness, low interest in communication, can show helplessness in social contacts and rise of adults' help dependence [6].

Unfortunately, there are not so many papers that discover some communicating features among visually challenged children. The study of non-verbal means of communication has the particular importance because of some unique features of this defect.

A serious visual impairment, first of all, influenced badly on the process of perception, that can be characterized as a slow one with narrow vision and loss of accuracy [7]. As a result, visually challenged children have not full and proper, sometimes even perverted, not distinguished enough visual images, or representations.

It is very hard for visually challenged children to perceive visual signals from their partners in communication completely. Also they learn how to use non-verbal means of communication less spontaneously $[8,9]$.

Such children have less developed facial expressions and their knowledge of emotions is very limited. They do not know exactly how to express agreement or disagreement, approval, astonishment and other emotions [10].

It is usual for such children to use single and definite gestures and provide them with verbal explanations, inaccurate perception of gestures, inactivity.

Visually challenged children cannot perceive postures in the right way, and, of course, cannot reproduce them. As they cannot understand the meaning of certain 
postures, it is very hard for them to find out what is happening around them and the emotional state, that had caused it.

All in all, we can say that such children who have some difficulties in visual perception (e.g. gestures, facial expressions, miming) cannot understand the emotional state of a partner to the full extent.

However, based on A.R.Luria's idea of the role of the environment in a child's personality formation, and compensatory developing mechanisms [11] and also on some ideas of modern researchers that non-verbal means of communication are connected with social conditions and usually are formed during the life with the exception of means of affective expressiveness $[6,12]$, some special lessons on teaching children how to use non-verbal means of communication are introduced now in some special children's institutions.

The aim of our research is to distinguish differences in learning non-verbal means of communication (gestures, facial expressions, miming) among high preschool aged children who attend special lessons.

We have made a suggestion that there are differences in learning non-verbal means of communication between children with normal eyesight and visually challenged children and they can be divided into three levels: cognitive, emotional and behavioral. On the cognitive level we speak about child's ability to distinguish different kinds of gestures, facial expressions and miming; on the emotional level we take into account the ability to describe feelings and emotional states of a person that are relevant to these kinds of non-verbal communication; on behavioral level we can speak about the child's ability to show and represent some proposed kinds of gestures, facial expressions and miming.

\section{Methodology and Methods}

In this research we use the following modified by us methods: "The ABC of Mood" by N.L.Belopolskaya [13], "Silence game" by G.V.Grigorieva [10], "Understanding of gestures" by N.V.Pilipko [14] and "Understanding of Miming" by Sabin and Hardick modified by G.V. Grigorieva [10].

Modifying the techniques, we adhere to the following requirements to stimulating materials:

- Each technique should contain the same number of images (pictures); 
- The images (pictures) should represent the most common gestures, facial expressions, postures;

- The images (pictures) should have verbal equivalent;

- The images (pictures) should contain the information about different emotional states of people.

We have analyzed 36 preschool aged children, 18 of them were with normal eyesight and 18 of them were visually challenged children who attended special classes where they could learn how to use non-verbal means of communication.

The updated by us technique "The ABC of Mood" by N.L.Belopolskaya [13] was used to investigate some peculiarities in mastering the use of miming. Except for five facepatterns, that represent such expressions as joy, anger, fear, astonishment, sufferings we add one more - the expression of calmness. Also we change the procedure - the children should name the expressions, describe the feelings corresponding to them and to mime face-patterns. It allows us to analyze miming on three levels: cognitive, emotional and behavioral.

To study the gesture learning on behavioral level we use "Silence game" by G. V. Grigorieva [10], and to study it on emotional and cognitive levels we use "Understanding of gestures" by N.V.Pilipko [14].

The key point of "Silence game" by G.V.Grigorieva [10] is that the children should answer six questions using the gestures of greeting, pointing, not-knowing, prohibition, denial, agreement; the children should show the gestures, not name them.

We update the technique by N.V. Pilipko [14] in such a way that children should name (cognitive level) and describe feelings (emotional level), corresponding to the given gestures.

As stimulating materials, we use three communicative and three modal gestures. Modal gestures are the gestures of suffering, joy, thinking over. These gestures show the evaluation of things, people and environmental phenomena. Communicative gestures are gestures of request, warning, prohibition. These expressive gestures are understandable without any verbal context and have their own meaning in communication.

To study mime learning we use "Understanding of Miming" by Sabin and Hardick modified by G.V. Grigorieva [10]. It contains six graphic images of postures, three of them are simple and three of them are complicated. The simple postures consist of two expressive components: arm position and head tilt or turn of the head. We use expressive movements of arms, head leg position and body bending in a very 
complicated process of miming, so each one consists of four elements. The procedure of this technique was also modified to study the process of miming on the cognitive, emotional and behavioral levels.

\section{Results and Discussion}

The results, characterized the learning of non-verbal means of communication on the cognitive, emotional and behavioral levels among children with normal eyesight and visually challenged children, were analyzed by the Stewdent and Fisher's criterion and are represented in Table 1.

TABLE 1: Differences in learning non-verbal means of communication among children with normal eyesight and visually challenged children on emotional and behavioral levels (according to Stewdent and Fisher's criterion).

The level of learning
non-verbal means of
communication
Cognitive level
Behavioural level

$\begin{gathered}\text { Mastering the facial } \\ \text { expressions }\end{gathered}$
$t=0,143 \mathrm{~F}=0,017$
$t=0,327 \mathrm{~F}=0,004$
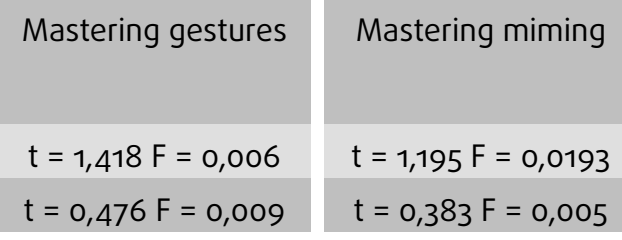

As we can see from Table 1, the differences between the levels of children with normal eyesight and visually challenged children are unreliable. So, we can say that children from both groups show us the similar level of learning facial expressions, gestures and miming on cognitive and behavioral levels.

The qualitative analysis shows us that in naming different facial expressions children from both groups made mistakes in defining the expression of calmness, that reflects neutral emotional state, that is more common for people, that is why the children can notice it very rarely. The most part of the children confused the expressions of fear and surprise, as they are quite similar. The analysis of gesture learning on cognitional level shows us that the children from both groups confused the gestures of not-knowing, negation and prohibition.

Consequently, we can make a conclusion that high preschool aged children cannot distinguish similar gestures well. These results are consistent to the previous ones $[15,16]$.

In defining miming the children from both groups were equally right in naming (cognitional level) and showing (behavioral level) simple and complicated postures.

The results of learning non-verbal means of communication on emotional level were analyzed qualitatively. All the answers were divided into three groups. The first 
group consists of children's answers that represent the descriptions of physical characteristics; the second group consists of answers that represent the descriptions of actions; and the third group consists of descriptions of emotional states of a person with certain facial expression, gesture or posture. The third group was subdivided into two subgroups: 1) the emotional states connected with the situation, and 2) the emotional states that are not connected with the situation (in this last case the child just name the emotion, but doesn't describe the emotional state, as it was asked in the task).

The analysis of the results of mastering miming (the emotional component) based on the technique "The ABC of Mood" by N.L.Belopolskaya [13] is shown in Table 2.

TABLE 2: The results of mastering facial expressions (the emotional component) among preschool aged children based on the technique "The ABC of Mood" by N.L.Belopolskaya.

Components
of mastering
the facial
expressions
Children with
normal
eyesight
Visually
challenged
children

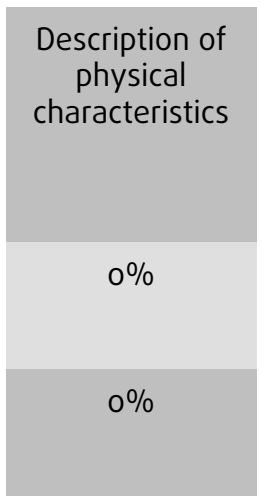

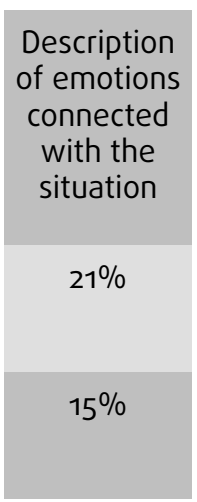
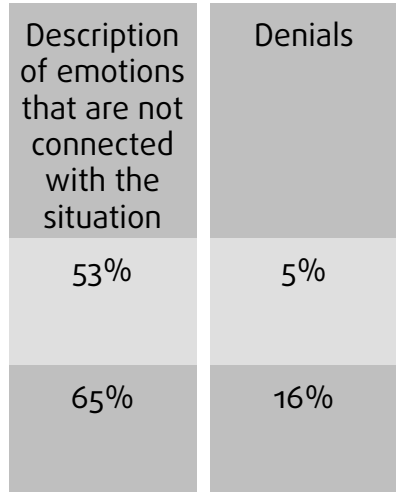

As we can see from the analysis, children with normal eyesight (27\%) describe emotional state through actions (e.g. "he has seen something", "he is looking at something") more frequently than visually challenged children (4\%)

Describing facial expressions, the children with normal eyesight connect them with the situations (21\%) more often than visually challenged children (15\%) (e.g. "he is happy, because he is given presents", "he is calm, he isn't in a hurry").

As we can see from the table, many children from both groups describe facial expressions without any connections with the situation. In this case they just name the facial expression once again, in other words, they just repeat the previous answer. We can only explain it that the children, relying on a short-term memory, announced the given answers, but it is very hard for them to describe feelings, that are usual for certain facial expressions.

As it concerns denials of describing facial expressions, we can make a conclusion that they, as describing gesture and miming, are not connected with eye problems (Tables 3 and 4). In our opinion, it can be explained by children's personal characteristics: shyness, difficulties in communication with others. 
Now let's analyze the results of gesture learning on the emotional level. They are represented in Table 3.

TABLE 3: The results of gesture learning (emotional component) of preschool aged children based on the "Silence game" by G.V.Grigorieva and "Understanding of gestures" by N.V.Pilipko.

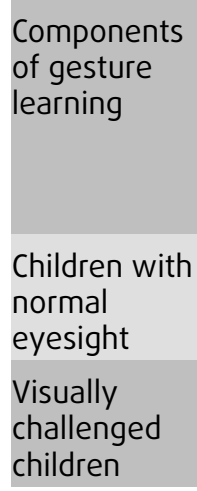
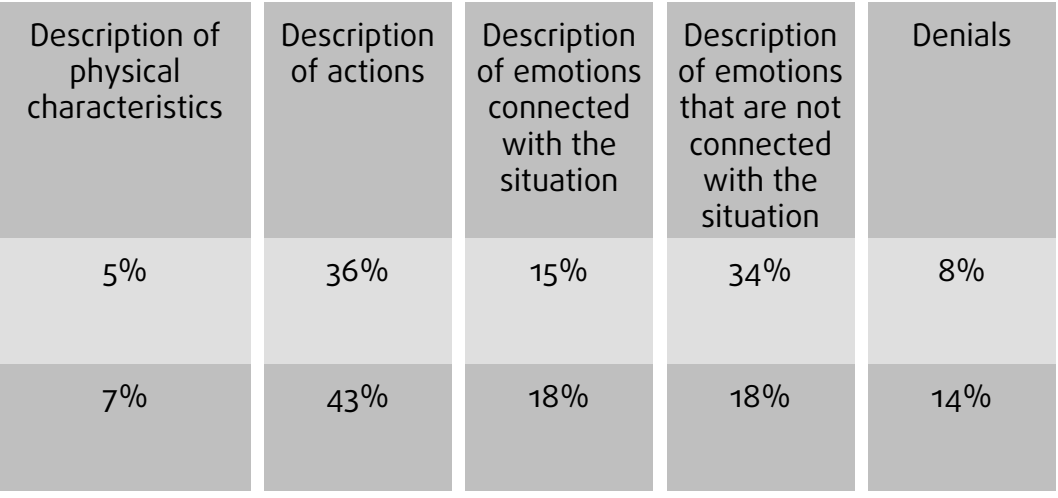

It should be noted, that there is a lot of children in both groups ( $5 \%$ and $7 \%$ ), who describe gestures through physical characteristics ("spread his arms", "made a cross"), so children of a high preschool age can describe non-verbal means of communication through such characteristics as actions and emotional states.

As we can see in Table 3, children with normal eyesight less often describe gestures through actions ("dancing", "forget the task") and connect the emotional state with the situation than visually challenged children ("he is happy because he has not seen for a long time", "he wants to hug his mother", etc.). More often (43\%) they describe an emotional state that isn't connected with the situation, in other words they just repeat the answer, that they have given on the level of cognition.

Now let's have a look at the results of mime learning which are shown in Table 4.

TABLE 4: The results of mastering miming (the emotional component) among preschool aged children based on the technique "Understanding of Miming" by Sabin and Hardick modified by G.V. Grigorieva.

Components
of mime
learning
Children with
normal
eyesight
Visually
challenged
children

\begin{tabular}{c}
$\begin{array}{c}\text { Description of } \\
\text { physical } \\
\text { characteristics }\end{array}$ \\
$0 \%$ \\
\hline $4 \%$
\end{tabular}
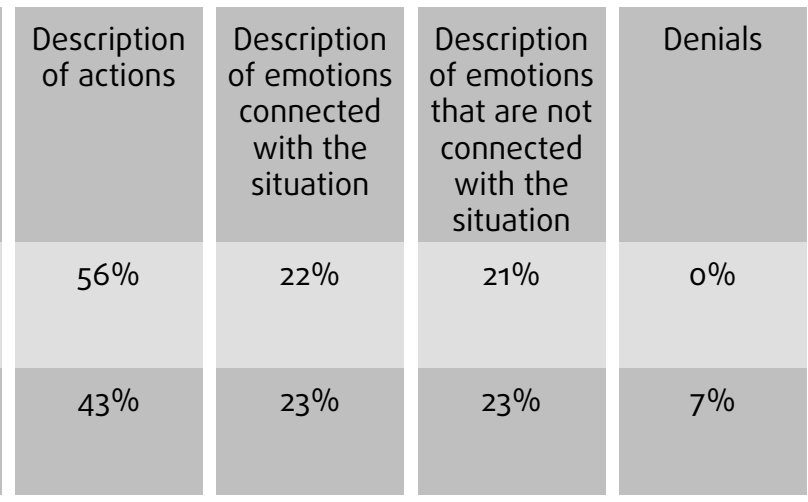
The analysis of Table 4 can show us that children with normal eyesight don't describe miming through physical characteristics at all, as compared to visually challenged children (e.g. "got down on his knees").

As we can see from the table, half of the children from both groups describe miming through actions, not through other characteristics ("he is fighting", "he is running", "he is late"). Perhaps this way of describing feelings and emotions is more affordable for children of this age. The other half of the children from both groups describe emotional states, represented in postures, and connect or do not connect them with certain situations (e.g. "he has fallen, he is hurt", "he is crying, because he has been offended"). The most difficult here is to describe posture through physical characteristics.

\section{Conclusions}

Based on A.R.Luria's ideas of educational compensatory mechanisms and on modern researcher's ideas of developing non-verbal means of communication in specially created situations we aim at studying differences in learning non-verbal means of communication (facial expressions, gestures, miming) by high preschool aged children with normal eyesight and visually challenged children who attend special classes.

As a result of our research we cannot define any significant differences on cognitive and behavioral levels among children with normal eyesight and visually challenged children. The qualitative analysis of learning non-verbal means of communication shows us children from both groups made mistakes in defining the expression of calmness, confused the expressions of fear and surprise, and gestures of not-knowing, denying and prohibition. It allows us to make a conclusion that preschool aged children cannot distinguish similar gestures and facial expressions well, independent from their eyesight. The children from both groups describe facial expressions, gestures and miming through actions, connecting them with the situations. That is due to focused thinking of high preschool aged children.

The results can be explained by the fact that in special kindergartens for visually challenged children there is special education aimed at learning non-verbal means of communication. It consists of introduction of non-verbal means of communication, role-playing, that can be characterized by certain types of facial expressions, gestures, postures, etc. So, visually challenged children of a high preschool age have the ability to compensate in developing non-verbal means of communication. These results are consistent with the V.A. Kruchinin's results about some features in development of 
visually challenged children in the process of school learning \{17] and once again prove the A.R.Luria's idea of role of the environment in a child's personality formation.

Therefore, children with normal eyesight rarely describe gestures through actions and connect emotional state with the situation, but more often define miming through description of physical characteristics. These results may be connected with eyesight problems, but should be proven on a large sample.

\section{References}

[1] Zemczova, M. (2006). Obuchenie i vospitanie doshkol'nikov s narusheniyami zreniya, Moskva, Prosveshhenie.

[2] Torres, A., Korn L. (1990). Slabovidyashhij Rebenok: Sovety' dlya Prepodavatelej, N'yu Jork, Gilford Press.

[3] Litvak, A. Puti korrekcii i integracii invalidov po zreniyu: korrekciya ili profilaktika? Defektologiya. No 8, pp.32-37. 2007.

[4] Ermakov, G. (2008). Razvitie, obuchenie i vospitonie detej s narusheniyami zreniya. Moskva, Prosveshhenie.

[5] Vy'gotskij, L. (1982). Sobranie sochineniya v 6 t. vol.5. Moskva, Pedagogika.

[6] Plaksina, L. (1998). Teoreticheskie osnovy' korrekcionnoj raboty’ v detskix sadax dlya detej s narusheniem zreniya. Moskva, Prosveshhenie.

[7] Vospitonie slepy'x detej doshkol'nogo vozrasta v sem'e (2009). Nauchny'j redaktor V. A. Feoktistova. Moskva, Logos.

[8] Bodalev, A. (1982). Vospriyatie i ponimanie cheloveka chelovekom. Moskva, Izdatelstvo Moskovskogo universiteta.

[9] Labunskaya, V. (1996). Neverbal'noe povedenie. Rostov, Izd-vo Rostovskogo universiteta.

[10] Grigor'eva, G. Osobennosti vladeniya neverbal'ny'mi sredstvami obshheniya doshkol'nikami s narusheniyami zreniya, Defektologiya. No 6, pp.18-24. 2010.

[11] Luria, A. (2012). Vy'sshie korkovy'e funkcii i ix narushenie pri lokal'ny'x porazheniyax mozga. Moskva, Kniga po trebovaniyu.

[12] Solnceva, L. Nekotory'e osobennosti psixicheskogo razvitiya detej s narusheniyami zreniya v sovremenny'x usloviyax, Defektologiya. No 4, pp. 45-49. 2000.

[13] Belopol'skaya, N. (2008). Azbuka nastroenij. E'mocional'no-kommunikativnaya igra dlya detej 4-10 let. Moskva, Kogito-Centr.

[14] Pilipko, N. (2000). Priglashenie v mir obshheniya. Moskva, Logos. 
[15] Deniskina, V. (2004). Osobennosti obucheniya social'no-by'tovoj orientirovke detej s narusheniem zreniya. placeCityUfa: Izd-vo Filiala MGOPU im. M. A. Sholoxova v g. Ufe.

[16] Ermolovich, Z. (2007). Rechevoe i lingvisticheskoe razvitie slabovidyashhix uchashhixsya nachal'noj shkoly. Moskva, Pedagogika.

[17] Kruchinin, V. (2007). Formirovanie prostranstvennoj orientirovki u detej $s$ narusheniyami zreniya v processe shkol'nogo obucheniya. Sankt-Peterburg: RGPPU. 